\title{
A Drug-Drug Salt Hydrate of Norfloxacin and Sulfathiazole: Enhancement of in Vitro Biological Properties via Improved
}

Shanmukha Prasad Gopi, Somnath Ganguly and Gautam R. Desiraju*

Solid State and Structural Chemistry Unit, Indian Institute of Science, Bangalore 560012, India

Email: desiraju@sscu.iisc.ernet.in

\section{Supporting Information}

\section{Index}

\begin{tabular}{|c|c|}
\hline Description & Page No. \\
\hline Figure S1 Crystal structures of NF-ST solvate $\mathrm{CH}_{3} \mathrm{OH}$ & S2 \\
\hline Figure S2 Crystal structures of NF-ST solvate $\mathrm{CH}_{3} \mathrm{CN}$ & S3 \\
\hline Figure S3 Crystal structures of NF-ST salt hydrate & S4 \\
\hline Table S1 Crystallographic parameters of NF-ST salts & S5 \\
\hline Figure S4 DSC endotherms and TGA of NF-ST salt hydrate. & S6 \\
\hline Table S2 Melting points $\left({ }^{\circ} \mathrm{C}\right)$ of the drug and its binary systems (DSC endotherms) & S6 \\
\hline Figure S5 FTIR spectra of NF-ST salt hydrate & S7 \\
\hline $\begin{array}{l}\text { Figure S6 PXRD comparison of simulated pattern and experimental pattern for NF-ST salt } \\
\text { hydrate }\end{array}$ & S8 \\
\hline $\begin{array}{l}\text { Table S3 Solubility values of NF, ST and salt in different } \mathrm{pH} \text { buffers and in } \\
\text { cosolvent }\end{array}$ & S9 \\
\hline $\begin{array}{l}\text { Table S4 MIC data and micro organisms count of NF-ST physical mixture and salt against } \\
\text { E. coli }\end{array}$ & S10 \\
\hline $\begin{array}{l}\text { Table S5 MIC data and micro organisms count of NF-ST physical mixture and salt against } \\
\text { S. aureus }\end{array}$ & S11 \\
\hline Figure S7 Antibacterial and fungal studies using disk diffusion technique & $\mathrm{S} 12, \mathrm{~S} 13$ \\
\hline Figure S8 Release/dissolution rate (IDR) comparison between NF and its salt & S14 \\
\hline Table S6 Quantitative determination of NF, ST by HPLC & S15 \\
\hline Figure S9 HPLC chromatograms of NF, ST, NF-ST salt and NF-ST physical mixtures & S16-S18 \\
\hline Experimental details and characterization techniques & $\mathrm{S} 18, \mathrm{~S} 19$ \\
\hline $\begin{array}{l}\text { Experimental procedures of solubility, diffusion studies, intrinsic dissolution rate and High } \\
\text { Performance Liquid Chromatography (HPLC) }\end{array}$ & $\mathrm{S} 19, \mathrm{~S} 20$ \\
\hline Experimental procedures of biological studies & S20, S21 \\
\hline
\end{tabular}




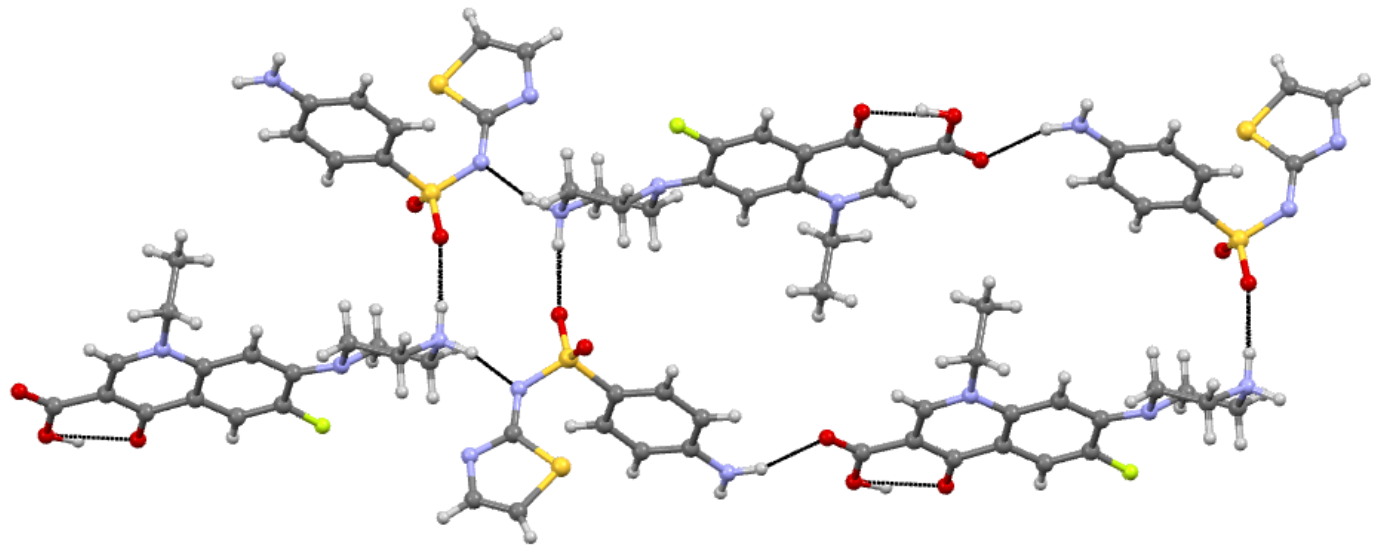

(a)
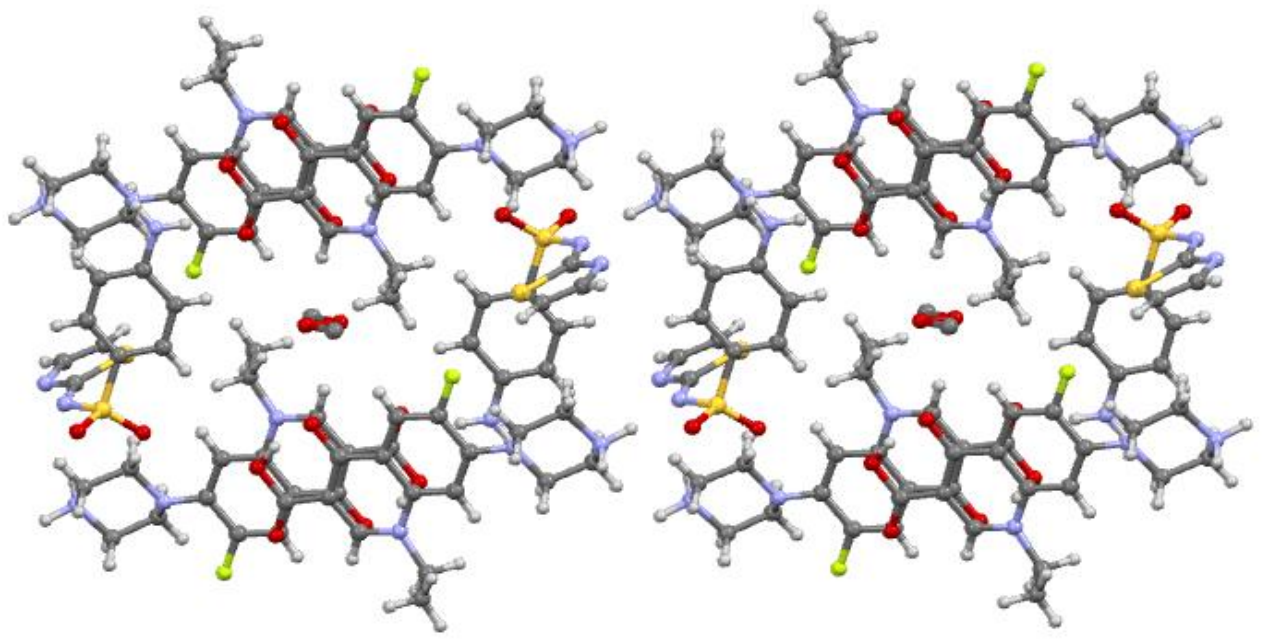

(b)

Figure S1 Crystal structures of NF-ST solvate $\mathrm{CH}_{3} \mathrm{OH}$. (a) Interactions (proton transfer from sulfonamide $_{\mathrm{ST}} \mathrm{N}-\mathrm{H}$ to piperizyl group of $\mathrm{NF} / \mathrm{N}-\mathrm{H} \cdots \mathrm{O}$ ) hydrogen bonding between NF-ST (c) Existence of methanol molecule in the cavity of the structure similar to hydrate 


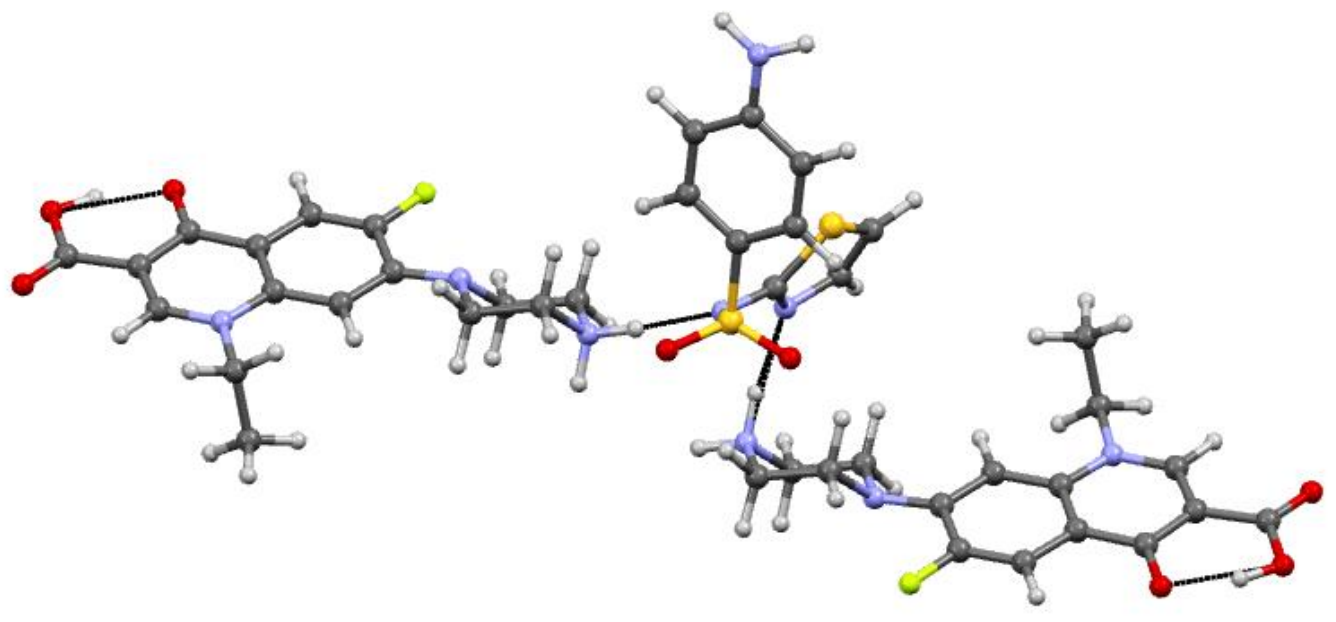

(a)

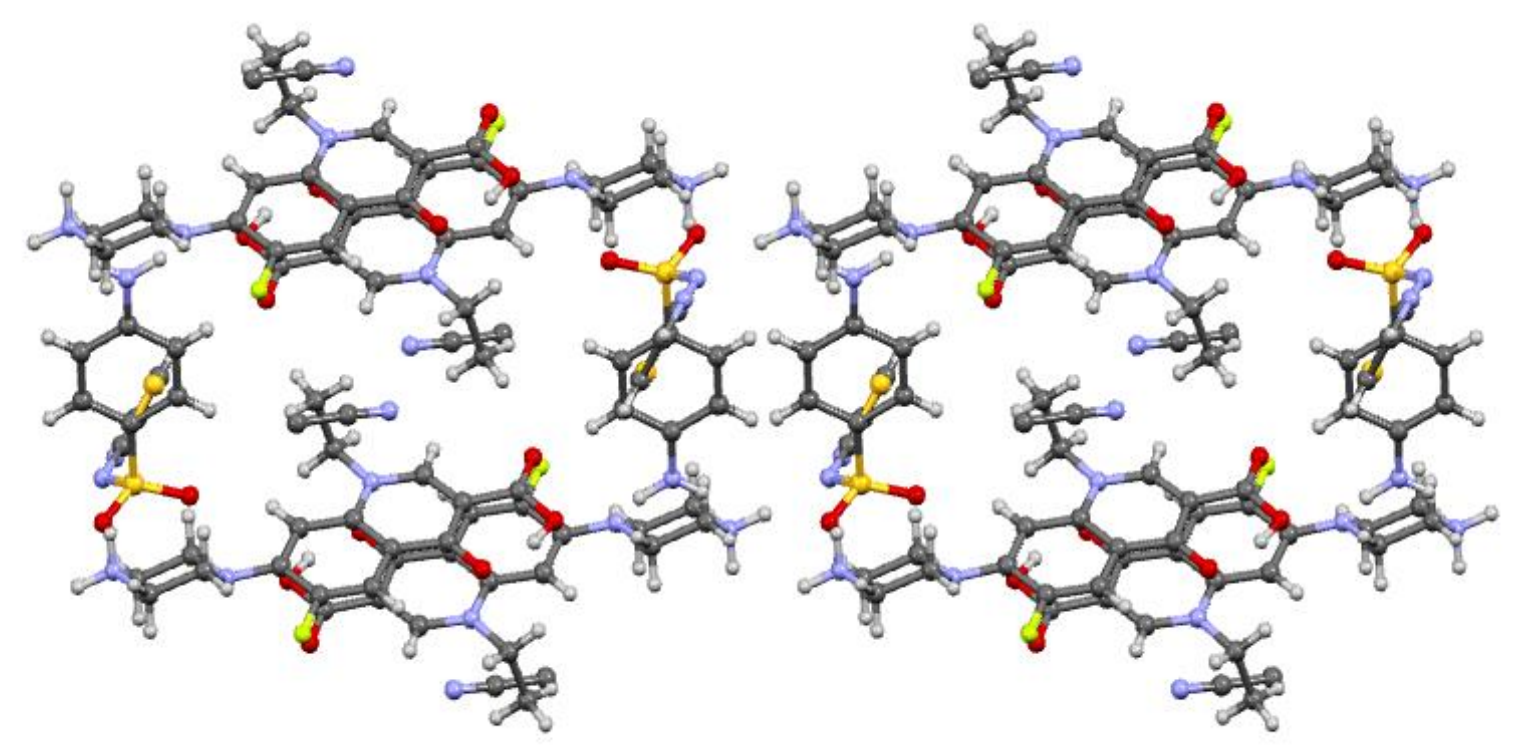

(b)

Figure S2 Crystal structures of NF-ST solvate $\mathrm{CH}_{3} \mathrm{CN}$. (a) Interactions (proton transfer from sulfonamide $_{\mathrm{ST}} \mathrm{N}-\mathrm{H}$ to piperizyl group of NF) hydrogen bonding between NF-ST (c) Existence of acetonitrile molecule in the cavity of the structure 

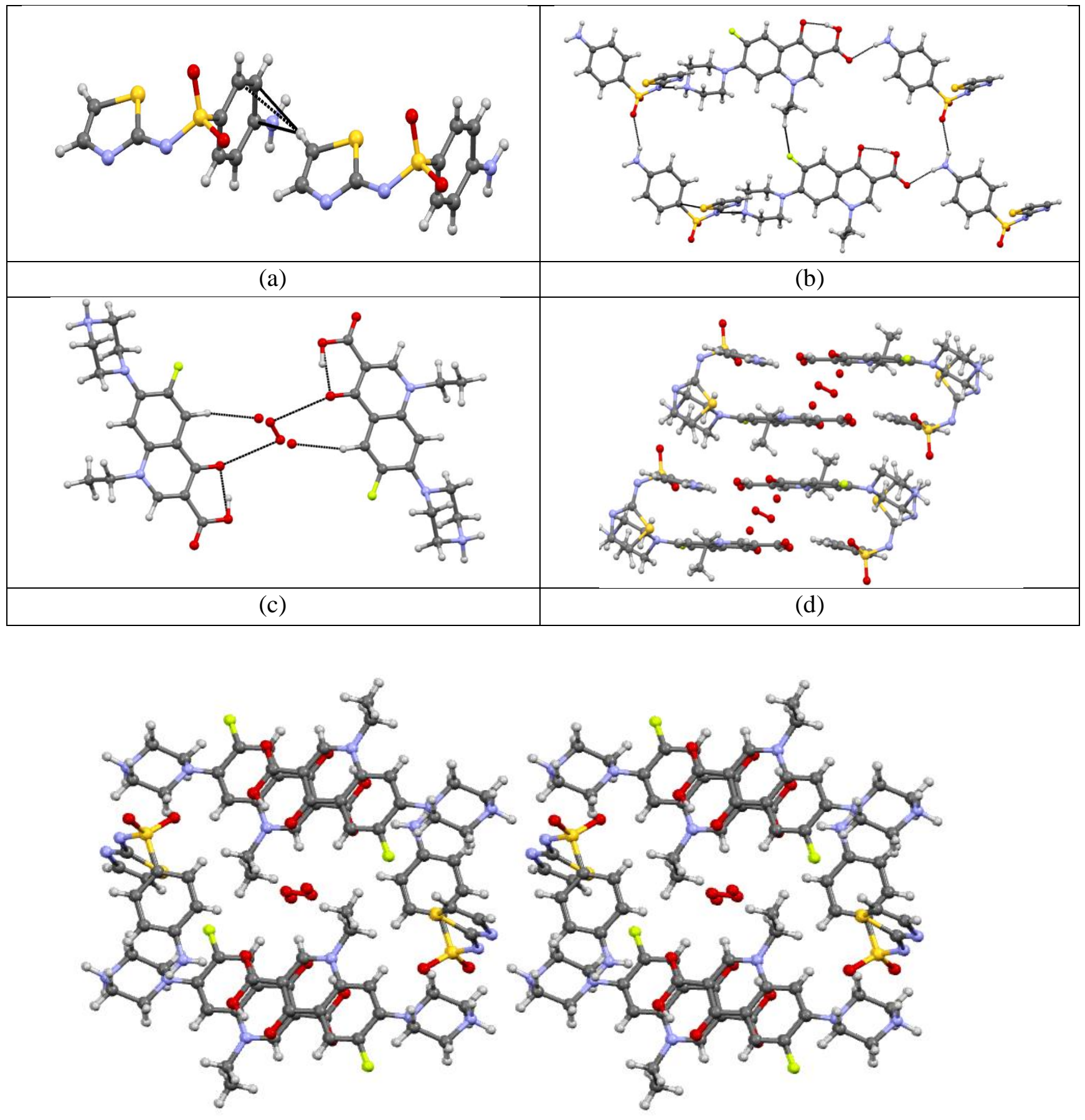

(d)

Figure S3 (a,b,c) Auxiliary $(\mathrm{C}-\mathrm{H} \cdots \pi / \mathrm{C}-\mathrm{H} \cdots \mathrm{F} / \mathrm{O}-\mathrm{H} \cdots \mathrm{O} / \mathrm{C}-\mathrm{H} \cdots \mathrm{O})$ hydrogen bonding between NFST and disordered hydrate molecule (d, e) Existence of water molecule in between the sheet structure/ cavity of the struture 


\begin{tabular}{|c|c|c|c|}
\hline & $\begin{array}{c}\text { NF-ST monohydrate } \\
(1: 1: 1)\end{array}$ & $\begin{array}{c}\text { NF-ST. } \mathrm{CH}_{3} \mathrm{OH} \\
\text { solvate }(1: 1: 1)\end{array}$ & $\begin{array}{c}\text { NF-ST } \mathrm{CH}_{3} \mathrm{CN} \\
(1: 1: 1)\end{array}$ \\
\hline Emp. Formula & $\begin{array}{l}\mathrm{C}_{16} \mathrm{H}_{18} \mathrm{FN}_{3} \mathrm{O}_{3} . \\
\mathrm{C}_{9} \mathrm{H}_{9} \mathrm{~N}_{3} \mathrm{O}_{2} \mathrm{~S}_{2 .} \mathrm{H}_{2} \mathrm{O}\end{array}$ & $\begin{array}{l}\mathrm{C}_{16} \mathrm{H}_{18} \mathrm{FN}_{3} \mathrm{O}_{3} . \\
\mathrm{C}_{9} \mathrm{H}_{9} \mathrm{~N}_{3} \mathrm{O}_{2} \mathrm{~S}_{2 .} \mathrm{CH}_{3} \mathrm{OH}\end{array}$ & $\begin{array}{c}\mathrm{C}_{16} \mathrm{H}_{18} \mathrm{FN}_{3} \mathrm{O}_{3} . \\
\mathrm{C}_{9} \mathrm{H}_{9} \mathrm{~N}_{3} \mathrm{O}_{2} \mathrm{~S}_{2 .} \mathrm{CH}_{3} \mathrm{CN}\end{array}$ \\
\hline Formula wt. & 592.65 & 606.69 & 615.7 \\
\hline Crystal system & Triclinic & Triclinic & Triclinic \\
\hline Space group & $P 1$ & $P 1$ & $P 1$ \\
\hline $\mathrm{T} / \mathrm{K}$ & $150(2)$ & $150(2)$ & $150(2)$ \\
\hline $\mathrm{a}(\AA)$ & $8.430(3)$ & $8.427(4)$ & $9.1393(10)$ \\
\hline $\mathrm{b} / \AA$ & $9.367(4)$ & $9.357(4)$ & $9.2064(10)$ \\
\hline $\mathrm{c} / \AA ̊ \mathrm{~A})$ & $18.192(7)$ & $18.170(8)$ & $18.3320(19)$ \\
\hline$\alpha /^{\circ}$ & $83.654(13)$ & $83.685(13)$ & $89.184(4)$ \\
\hline$\beta /{ }^{\circ}$ & $86.188(14)$ & $86.111(12)$ & $82.936(4)$ \\
\hline$\gamma /{ }^{\circ}$ & $73.615(7)$ & $73.52(1)$ & $73.496(4)$ \\
\hline Volume $/ \AA^{3}$ & $1368(9)$ & $1364.5(11)$ & $1467.3(3)$ \\
\hline$D_{\text {calcd }}\left(\mathrm{g} \mathrm{cm}^{-3}\right)$ & 1.433 & 1.433 & 1.387 \\
\hline $\mathrm{Z}$ & 2 & 2 & 2 \\
\hline $2 \theta$ range & 2.9 to 25.9 & 2.9 to 33.8 & 2.1 to 27.5 \\
\hline $\begin{array}{l}\mathrm{R}_{1}(\mathrm{I}>2 \sigma(\mathrm{I})), \\
\mathrm{wR}_{2}\end{array}$ & $0.0422,0.1224$ & $0.0488,0.1336$ & $0.0403,0.1193$ \\
\hline GOF & 1.036 & 1.085 & 0.965 \\
\hline Diffractometer & Rigaku-CCD & Rigaku-CCD & Rigaku-CCD \\
\hline CCDC Nos. & 1452815 & 1452814 & 1452813 \\
\hline
\end{tabular}

Table S1 Crystallographic parameters of NF-ST salts 


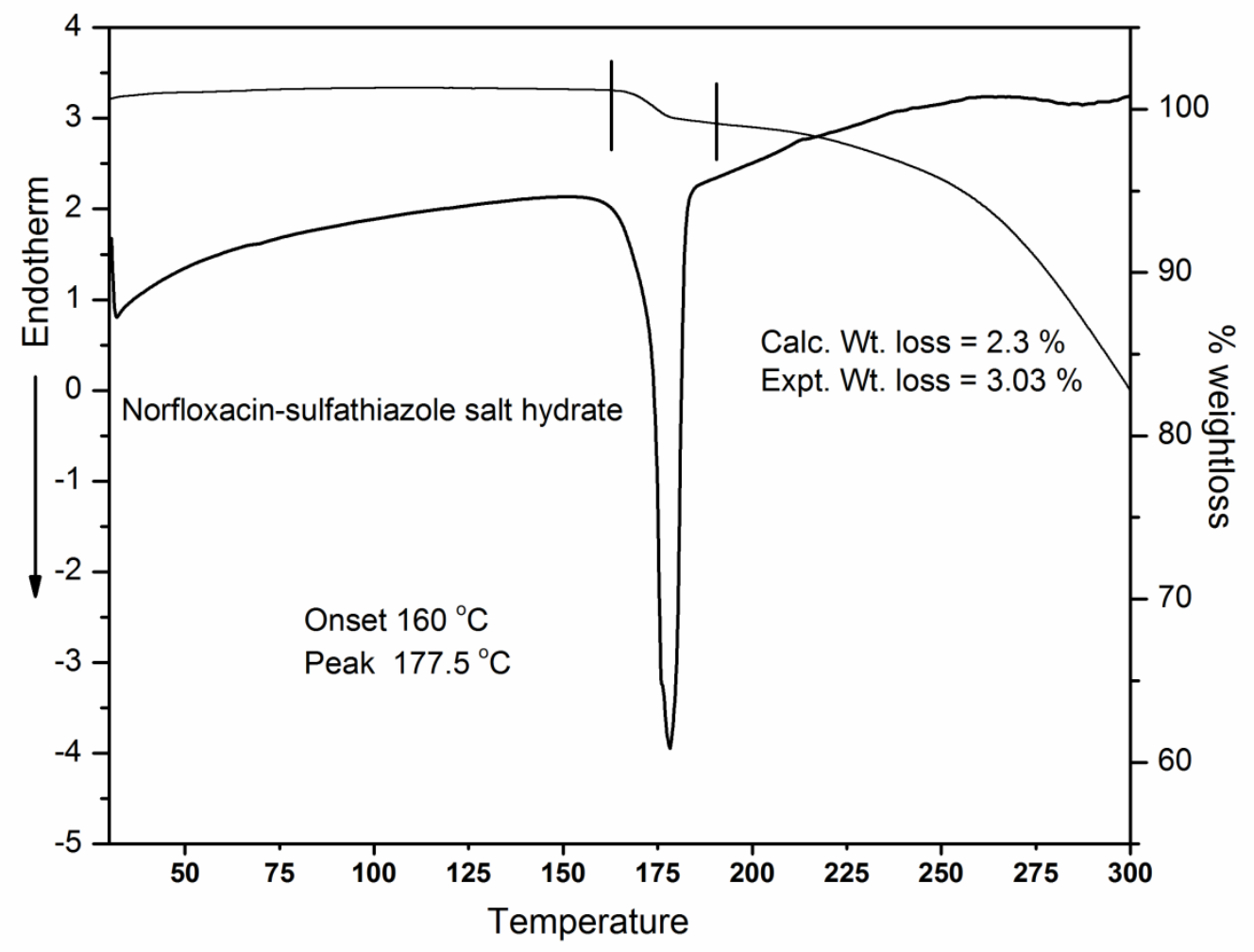

Figure S4 DSC endotherms and TGA of NF-ST salt hydrate.

\begin{tabular}{|l|c|}
\hline API's and its new solid forms & m.p. $\left({ }^{\circ} \mathbf{C}\right)$ \\
\hline Norfloxacin & $220-221$ \\
\hline Sulfathiazole & $201-203$ \\
\hline NF-ST salt hydrate & $175-178$ \\
\hline NF-ST salt $\mathrm{CH}_{3} \mathrm{OH}$ solvate & $172-174$ \\
\hline NF-ST salt $\mathrm{CH}_{3} \mathrm{CN}$ solvate & $176-181$ \\
\hline
\end{tabular}

Table S2 Melting points $\left({ }^{\circ} \mathrm{C}\right)$ of the drug and its binary systems (DSC endotherms) 


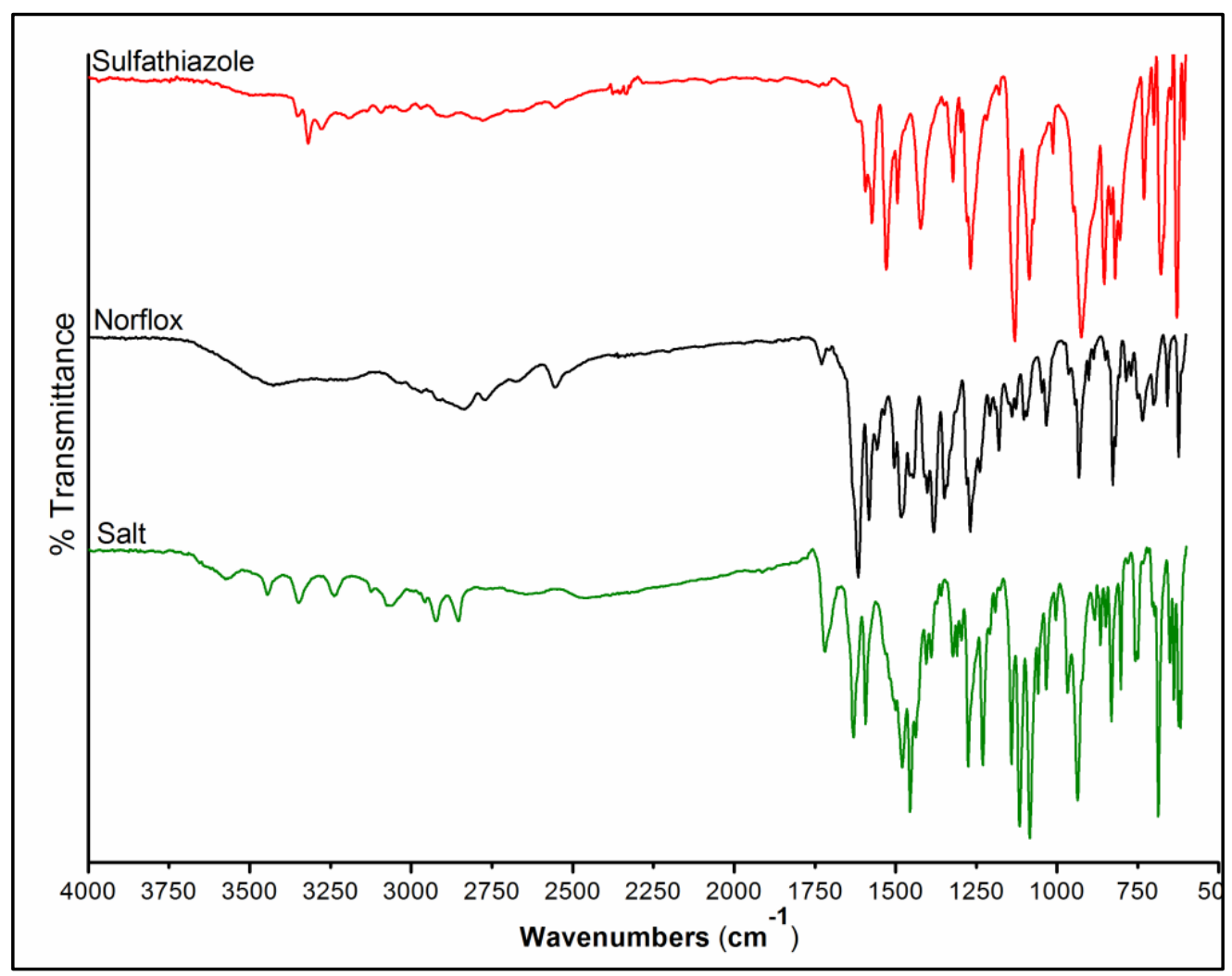

Figure S5 (a) FTIR spectra of NF, ST and its salt hydrate

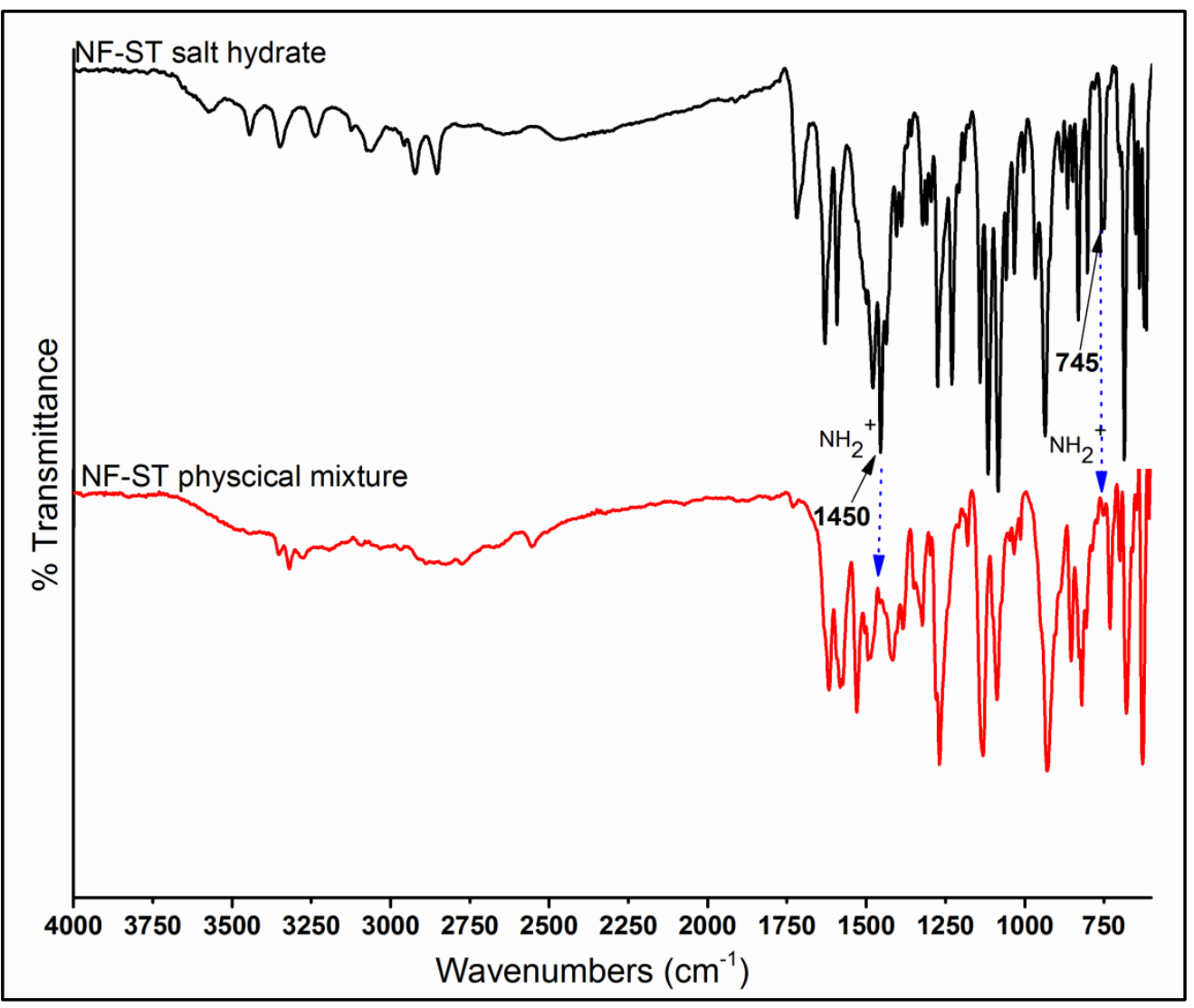

Figure S5 (b) IR spectra of NF-ST salt hydrate and its grounded physical mixture 

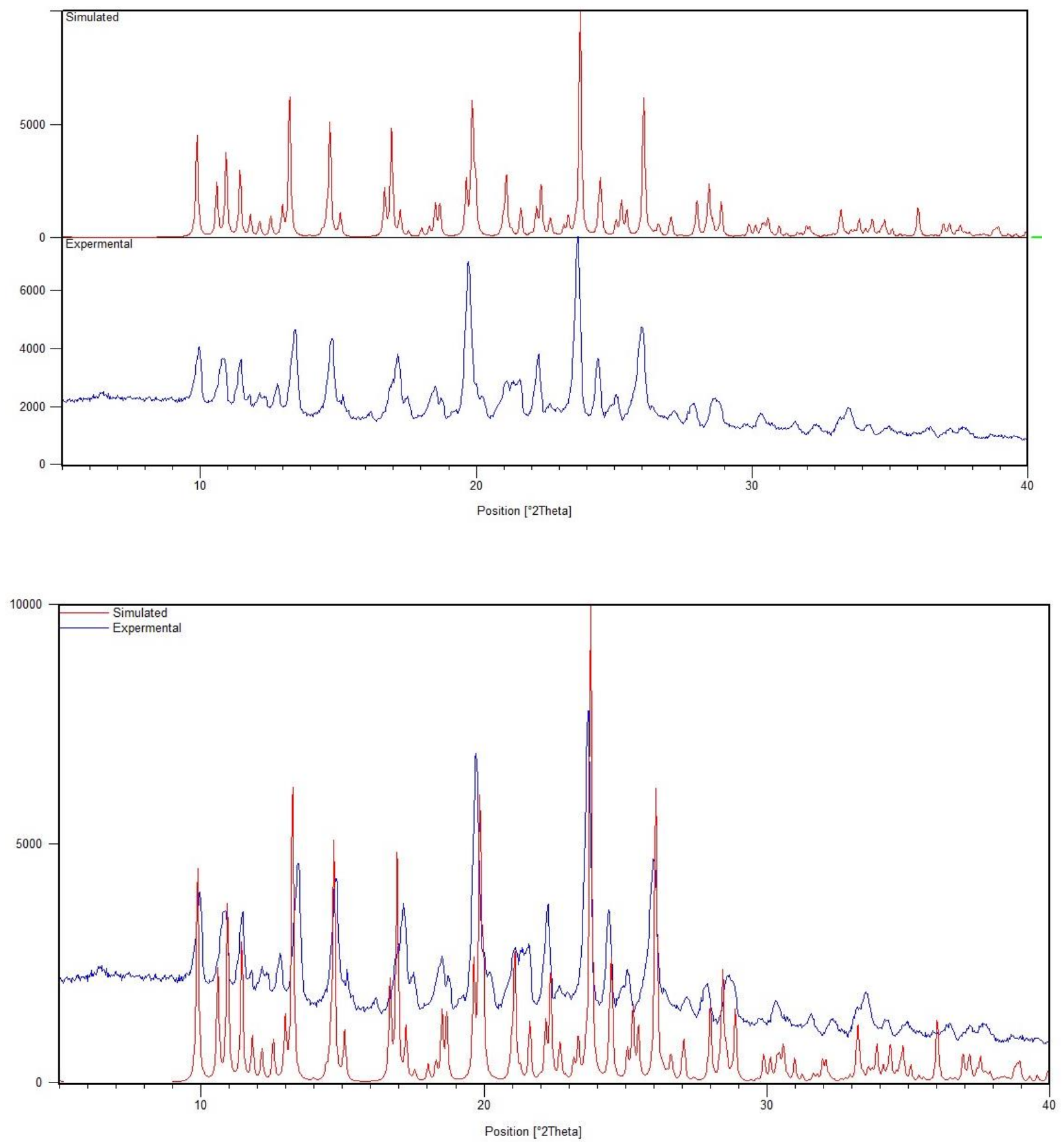

Figure S6 PXRD comparison of simulated pattern and experimental pattern for NF-ST salt hydrate 


\begin{tabular}{|c|c|c|c|c|c|}
\hline \multirow[t]{2}{*}{ Solubility medium } & \multirow{2}{*}{$\begin{array}{c}\mathrm{NF} \\
\mathrm{mg} / \mathrm{L}\end{array}$} & \multirow{2}{*}{$\begin{array}{c}\text { ST } \\
\mathrm{mg} / \mathrm{L}\end{array}$} & \multirow{2}{*}{$\begin{array}{l}\text { Salt } \\
\mathrm{mg} / \mathrm{L}\end{array}$} & \multicolumn{2}{|c|}{$\begin{array}{l}\text { Molar contribution of the } \\
\text { salt }(\mathrm{mg} / \mathrm{L})\end{array}$} \\
\hline & & & & $\mathbf{N F}$ & ST \\
\hline pH 7.4 & 178 & 703 & 1360 & 735 & 585 \\
\hline pH 4.0 & 221 & 316 & 1198 & 647 & 515 \\
\hline pH 1.2 & 17793 & 2895 & 24022 & 12972 & 10329 \\
\hline $\begin{array}{c}\text { Cosolvent } \\
(\mathrm{pH} 7.4 \\
\text { buffer+10\% EtOH) }\end{array}$ & 513 & 1715 & 6166 & 3330 & 2651 \\
\hline
\end{tabular}

Table S3 Solubility values of NF, ST and salt in different $\mathrm{pH}$ buffers and in cosolvent 


\title{
INHIBITION STUDIES:
}

\author{
Against Bacteria: Escherichia coli \\ Concentration: $1 \mathrm{mg} / \mathrm{ml}$ (Norflox : 0.55 + Sulfathiazole 0.45)
}

\begin{tabular}{|c|c|c|c|c|c|c|c|c|c|c|}
\hline $\begin{array}{c}\text { Drug } \\
\text { concentration } \\
\text { (ug/ml) }\end{array}$ & $\mathbf{5 0}$ & $\mathbf{2 5}$ & $\mathbf{1 2 . 5}$ & $\mathbf{6 . 2 5}$ & $\mathbf{3 . 1 2}$ & $\mathbf{1 . 6 1 2 5}$ & $\mathbf{0 . 8 0 6}$ & $\mathbf{0 . 4 0 3}$ & $\mathbf{0 . 2 0 1}$ & $\mathbf{0 . 1 0 0 7}$ \\
\hline $\begin{array}{c}\text { Physical mixture } \\
\text { on E. coli (Gram } \\
\text {-ve) Bacteria }\end{array}$ & 0.0517 & 0.062 & 0.0438 & 0.0676 & 0.0709 & $\begin{array}{c}\mathbf{0 . 0 7 3 7} \\
\text { MIC }\end{array}$ & $\begin{array}{c}\mathbf{0 . 1 8 6 5} \\
\text { Broad } \\
\text { bacteria } \\
\text { growth } \\
\text { noticed }\end{array}$ & 0.3018 & 0.3384 & 0.754 \\
\hline $\begin{array}{c}\text { salt on E. coli } \\
\text { (Gram -ve) } \\
\text { Bacteria }\end{array}$ & 0.0459 & 0.0451 & 0.0535 & 0.0476 & 0.0719 & 0.0714 & $\begin{array}{c}\mathbf{0 . 0 8 4 5} \\
\text { MIC }\end{array}$ & $\begin{array}{c}\mathbf{0 . 1 4 9 4} \\
\text { Broad } \\
\text { bacteria } \\
\text { growth } \\
\text { noticed }\end{array}$ & 0.3756 & 0.3576 \\
\hline
\end{tabular}
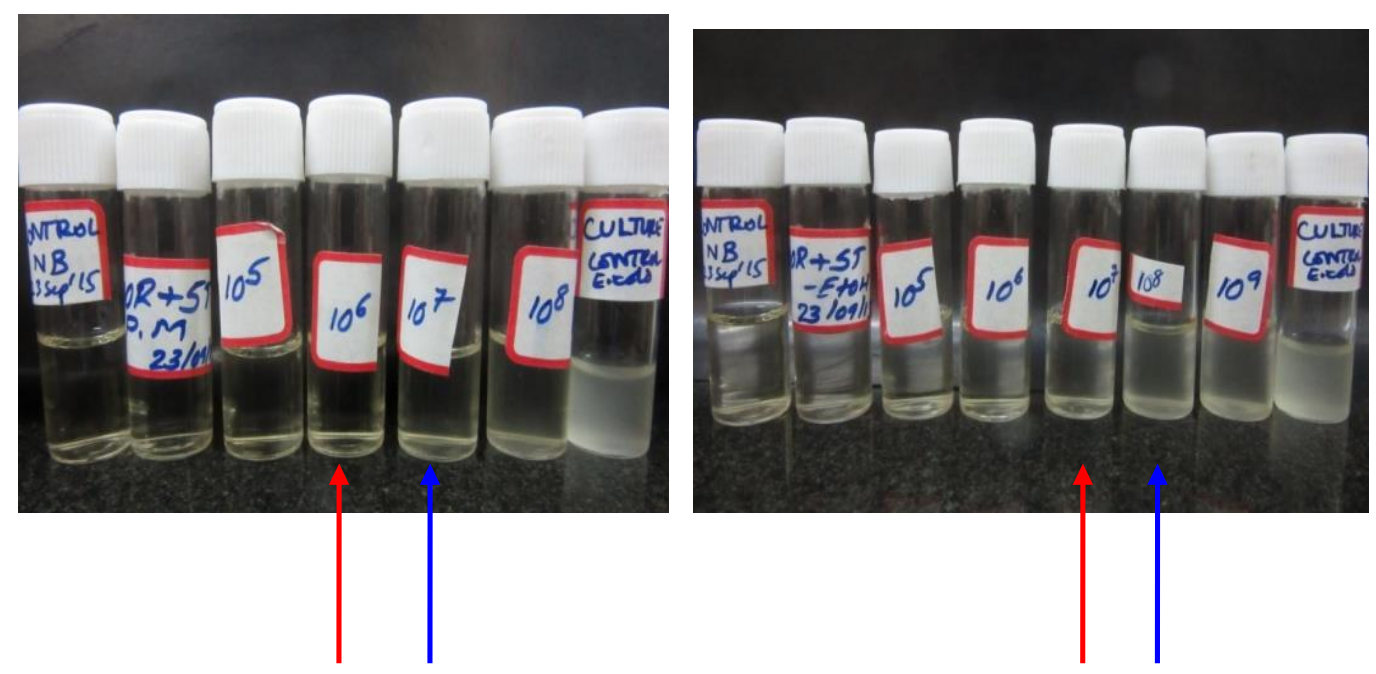

Table S4. MIC data and micro organisms culture of NF-ST physical mixture and salt against $E$. coli (Table indicates the MIC values in red color and broad bacterial growth in blue color). 
Against Bacteria: Staphylococcus aureus

Concentration: $1.8 \mathrm{mg} / \mathrm{ml}$ (Norflox : $1 \mathrm{mg}+$ Sulfathiazole $0.8 \mathrm{mg}$ )

\begin{tabular}{|c|c|c|c|c|c|c|c|c|c|c|}
\hline $\begin{array}{c}\text { Drug } \\
\text { concentration } \\
\text { (ug/m) }\end{array}$ & $\mathbf{5 0}$ & $\mathbf{2 5}$ & $\mathbf{1 2 . 5}$ & $\mathbf{6 . 2 5}$ & $\mathbf{3 . 1 2 5}$ & $\mathbf{1 . 6 2}$ & $\mathbf{0 . 8 0 6}$ & $\mathbf{0 . 4 0 3}$ & $\mathbf{0 . 2 0 1}$ & $\mathbf{0 . 1 0 0 7}$ \\
\hline $\begin{array}{c}\text { physical } \\
\text { mixture } \\
\text { on } S . \text { aureus } \\
\text { (Gram +ve) } \\
\text { bacteria }\end{array}$ & 0.0896 & 0.0851 & 0.0868 & 0.0851 & $\begin{array}{c}\mathbf{0 . 0 7 9 3} \\
\mathbf{M I C}\end{array}$ & $\begin{array}{c}\mathbf{0 . 1 8 7 6} \\
\text { Broad } \\
\text { bacteria } \\
\text { growth } \\
\text { noticed }\end{array}$ & 0.3356 & 0.4663 & 0.4011 & 0.3477 \\
\hline $\begin{array}{c}\text { Salt on } S . \\
\text { aureus } \text { (Gram } \\
\text { +ve) bacteria }\end{array}$ & 0.0859 & 0.0873 & 0.0972 & 0.0939 & 0.0968 & $\begin{array}{c}\mathbf{0 . 0 9 9 2} \\
\mathbf{M I C}\end{array}$ & $\begin{array}{c}\mathbf{0 . 2 6 8 8} \\
\text { Broad } \\
\text { bacteria } \\
\text { growth } \\
\text { noticed }\end{array}$ & 0.2774 & 0.2778 & 0.3403 \\
\hline
\end{tabular}
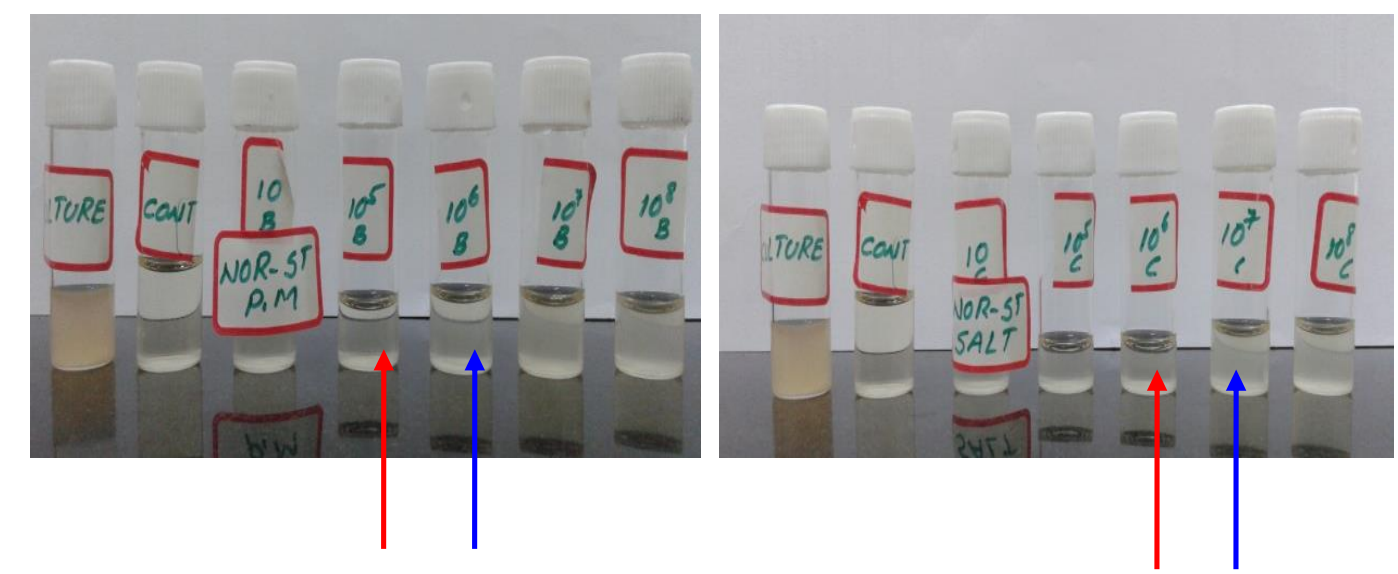

Table S5 MIC data and micro organisms culture of NF-ST physical mixture and salt against $S$. aureus (Table indicates the MIC values in red color and broad bacterial growth in blue color). 


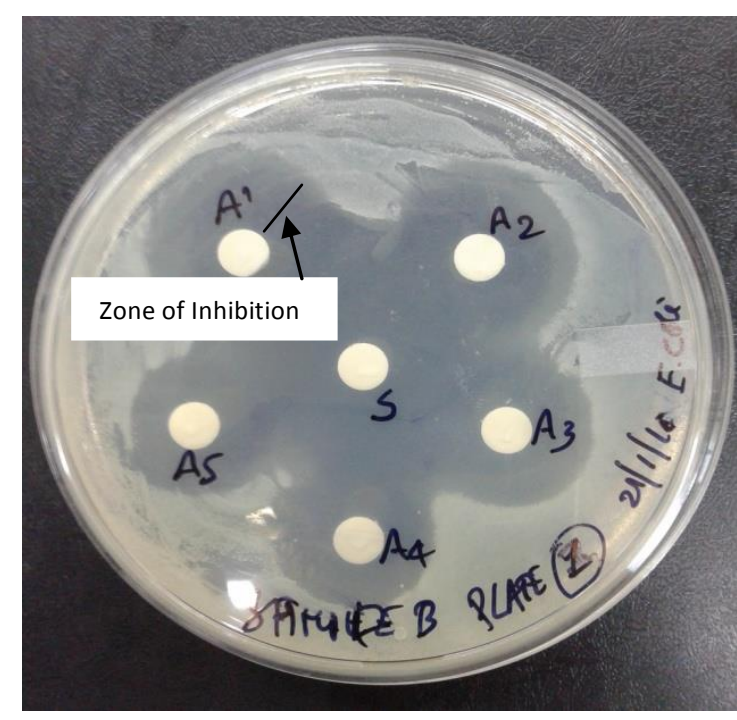

(a)

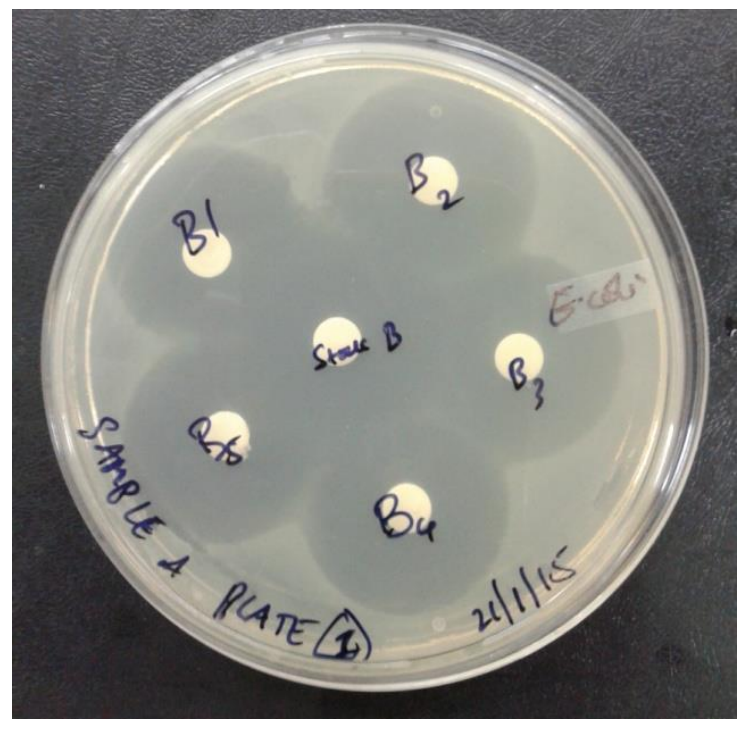

(c)

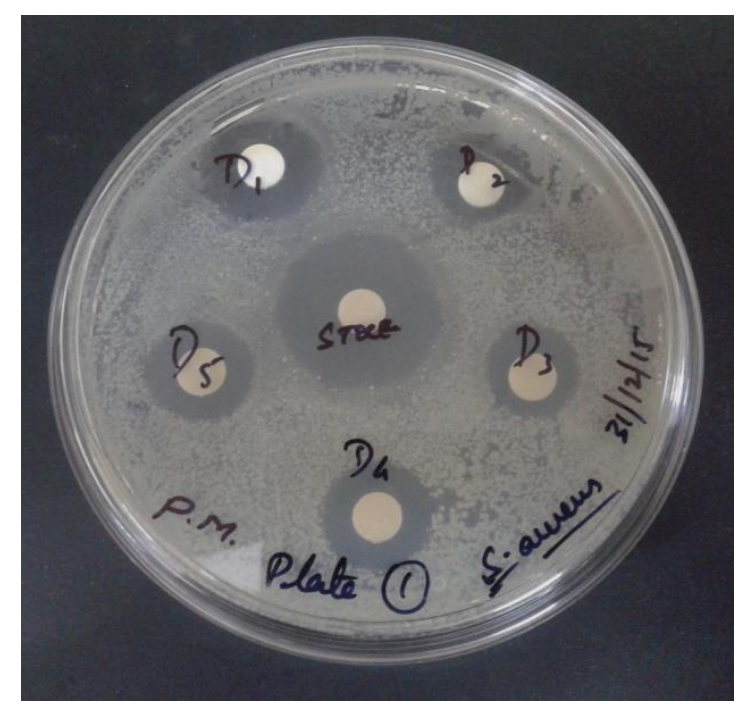

(e)

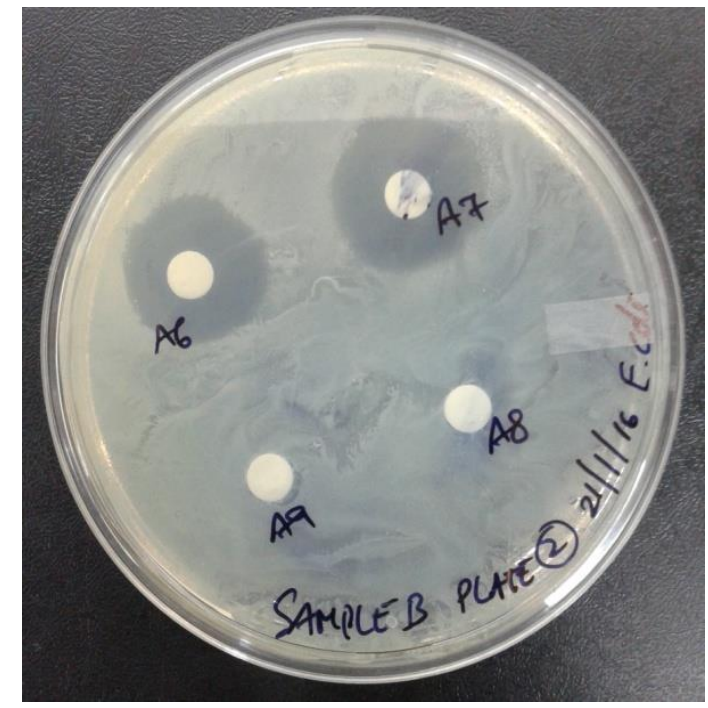

(b)

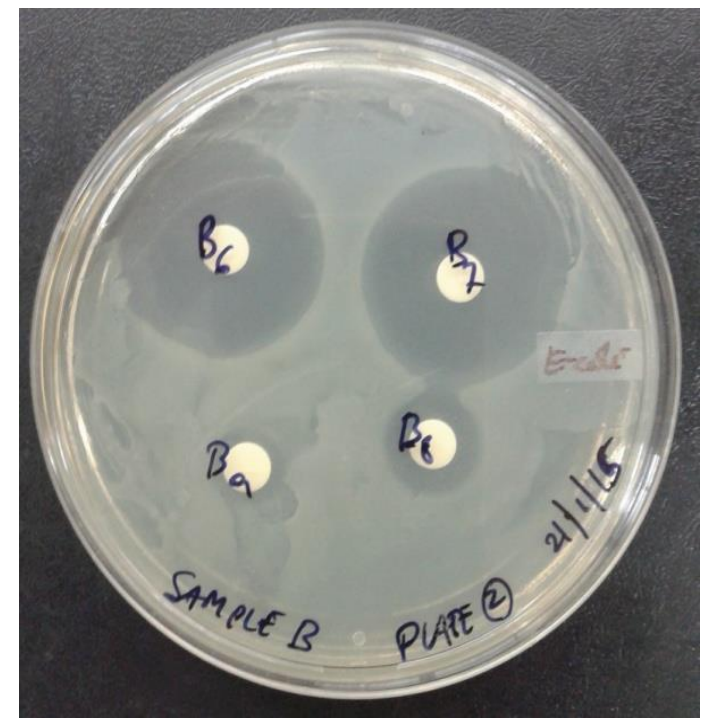

(d)

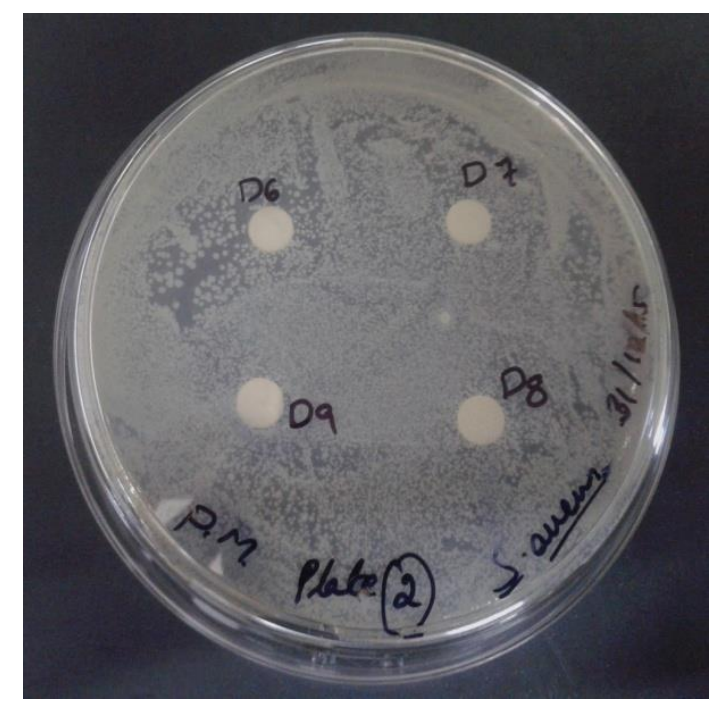

(f) 


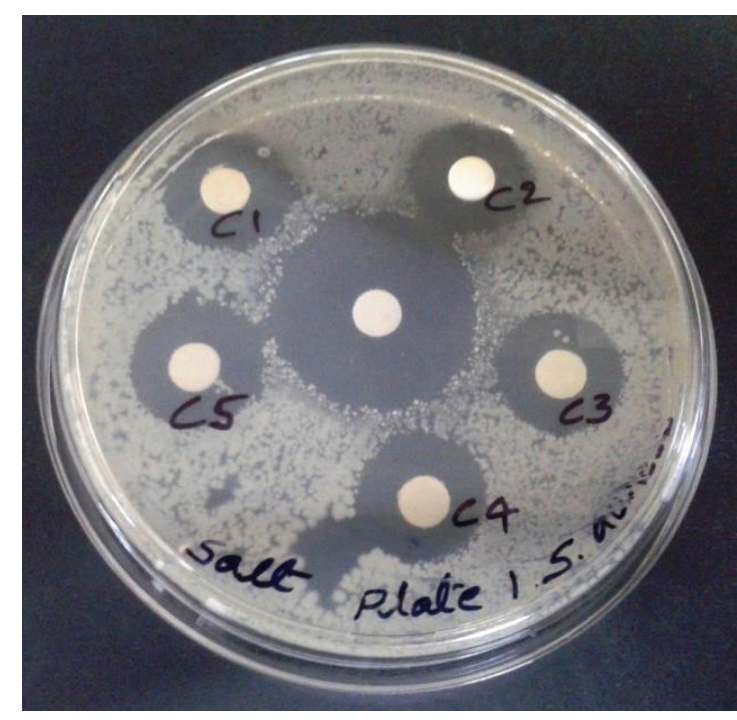

(g)

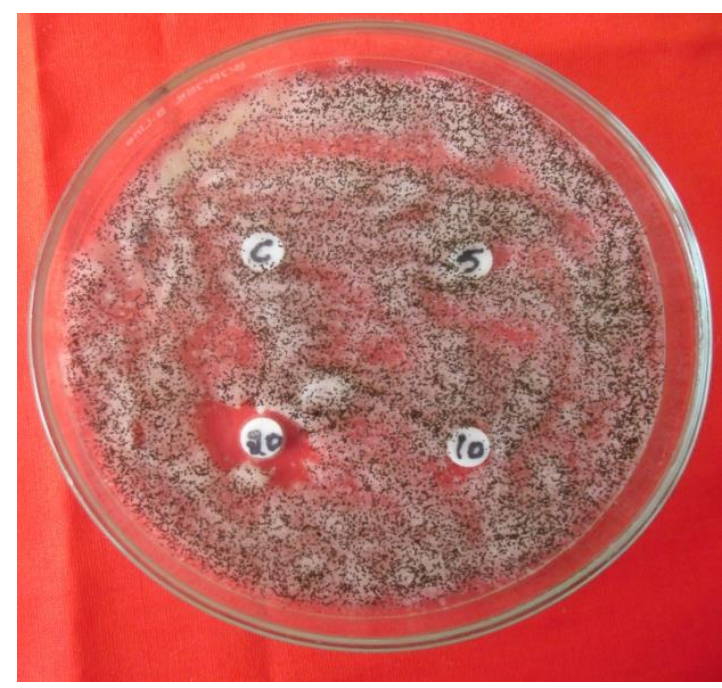

(i)

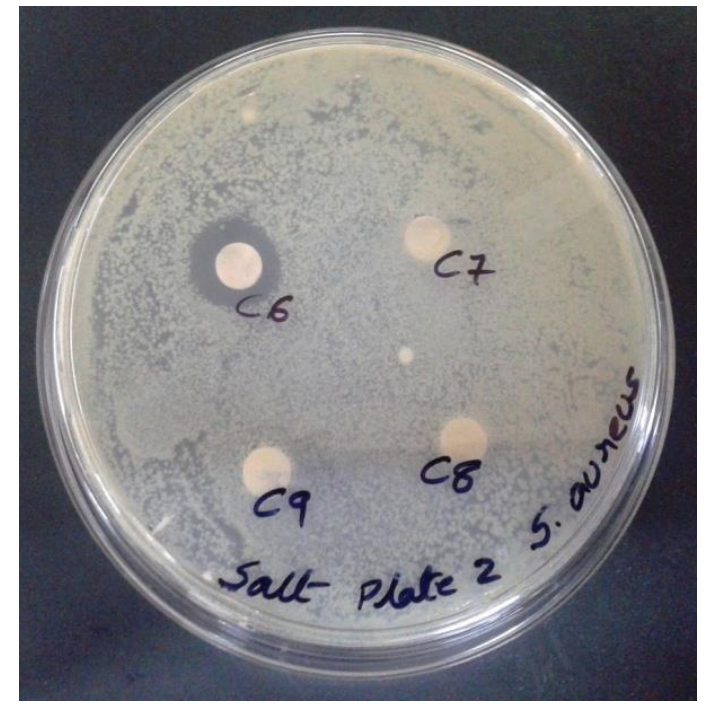

(h)

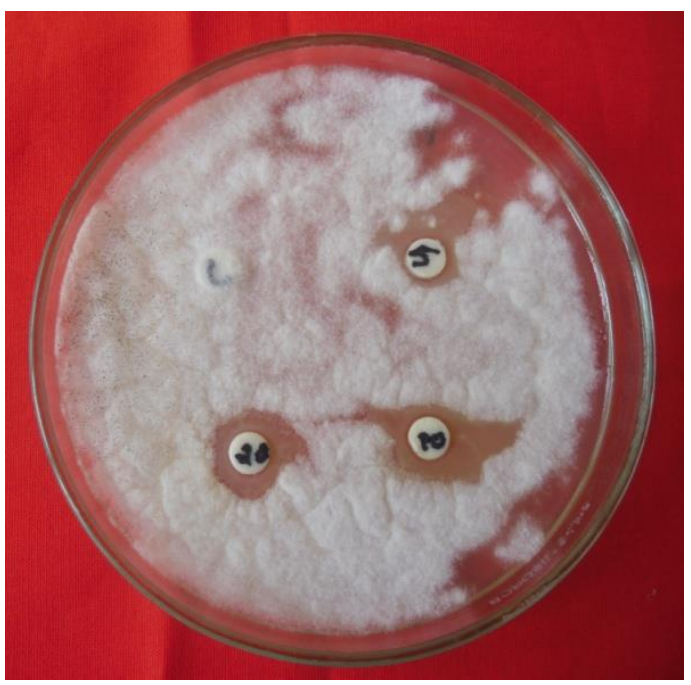

$(\mathbf{j})$

Figure S7 Antibacterial disk diffusion technique images against $(\mathrm{a}, \mathrm{b}) \mathrm{NF}-\mathrm{ST}$ physical mixture on $E$. coli (c,d) NF-ST salt on E. coli (e,f) NF-ST physical mixture on $S$. aureus (g,h) NF-ST salt on $S$. aureus (i) NF-ST physical mixture on Aspergillus (j) NF-ST salt on Aspergillus after five days.

Stock concentrations were used for disk diffusion technique $1 \mathrm{mg} / \mathrm{ml}$ (salt and P.M) against E. coli and Aspergillus and $1.8 \mathrm{mg} / \mathrm{ml}$ (salt and P.M) against S. aureus.

Concentrations used in disk diffusion technique for the plates (a-h).

\begin{tabular}{|c|c|c|c|c|c|c|c|c|c|c|}
\hline $\begin{array}{c}\text { Number } \\
\text { on disk }\end{array}$ & 1 & 2 & 3 & 4 & 5 & 6 & 7 & 8 & 9 & $\mathrm{~S}$ \\
\hline $\begin{array}{c}\text { Conc. } \\
(\mu \mathrm{g} / \mathrm{ml})\end{array}$ & 50.00 & 25.00 & 12.50 & 6.25 & 3.12 & 1.62 & 0.81 & 0.40 & 0.20 & $\begin{array}{c}\text { Stock } \\
\text { solution }\end{array}$ \\
\hline
\end{tabular}

In disks i and j "5 - $5 \mu \mathrm{g} / \mathrm{ml}, 10-10 \mu \mathrm{g} / \mathrm{ml}, 20-20 \mu \mathrm{g} / \mathrm{ml}$ " and "c" for control drug concentrations used against Aspergillus (stock solution concentration $2.2 \mathrm{mg} / \mathrm{ml}$ ) 


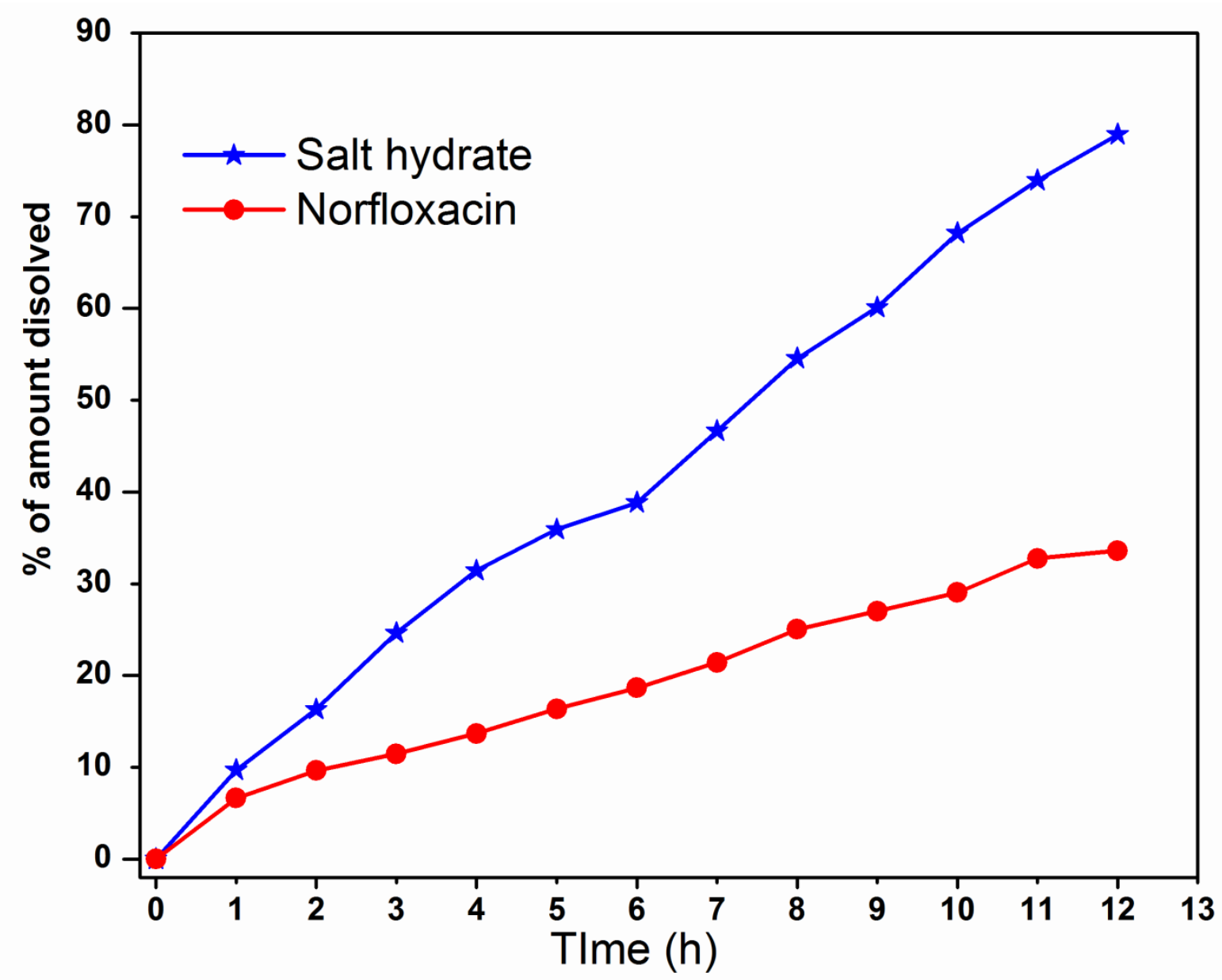

Figure S8 Release/dissolution rate (IDR) comparison between NF and its salt (average particle size of the NF is $\sim 1-2 \mu \mathrm{m}$ and for salt $\sim 0.5-1.5 \mu \mathrm{m}$ ) 


\section{Quantitative determination by HPLC}

\begin{tabular}{|c|c|c|c|c|}
\hline \multicolumn{5}{|c|}{ Norfloxacin (NF) } \\
\hline Apex RT & Start RT & End RT & Area & $\%$ Area \\
\hline 4.12 & 4.01 & 4.98 & 2492085 & 100 \\
\hline
\end{tabular}

\begin{tabular}{|c|c|c|c|c|}
\hline \multicolumn{5}{|c|}{ Sulfathiazole (ST) } \\
\hline Apex RT & Start RT & End RT & Area & $\%$ Area \\
\hline 2.4 & 2.34 & 2.59 & 3431725 & 100 \\
\hline
\end{tabular}

\begin{tabular}{|c|c|c|c|c|}
\hline \multicolumn{5}{|c|}{$\mathrm{NF}+\mathrm{ST}$ salt } \\
\hline \multicolumn{3}{|c|}{ Number of detected peaks: 2} & & \\
\hline Apex RT & Start RT & End RT & Area & $\%$ Area \\
\hline $2.4(\mathrm{ST})$ & 2.33 & 2.65 & 2212871 & 52 \\
\hline $4.17(\mathrm{NF})$ & 4.05 & 4.85 & 2042914 & 48 \\
\hline
\end{tabular}

\begin{tabular}{|c|c|c|c|c|}
\hline \multicolumn{5}{|c|}{ NF+ST physical mixture } \\
\hline Number of detected peaks: 2 \\
\hline Apex RT & Start RT & End RT & Area & \% Area \\
\hline $2.4(\mathrm{ST})$ & 2.32 & 2.64 & 2209075 & 56 \\
\hline $4.17(\mathrm{NF})$ & 4.03 & 4.94 & 1757301 & 44 \\
\hline
\end{tabular}

\begin{tabular}{|c|c|c|c|c|}
\hline \multicolumn{5}{|c|}{ NF+ST physical mixture (after 4 hours) } \\
\hline \multicolumn{5}{|c|}{ Number of detected peaks: 2} \\
\hline Apex RT & Start RT & End RT & Area & \% Area \\
\hline $2.4(\mathrm{ST})$ & 2.32 & 2.7 & 3871961 & 64 \\
\hline $4.17(\mathrm{NF})$ & 4.02 & 4.97 & 2193177 & 36 \\
\hline
\end{tabular}

Table S6. Peak area percentages of NF, ST, NF-ST salt and NF-ST physical mixtures 


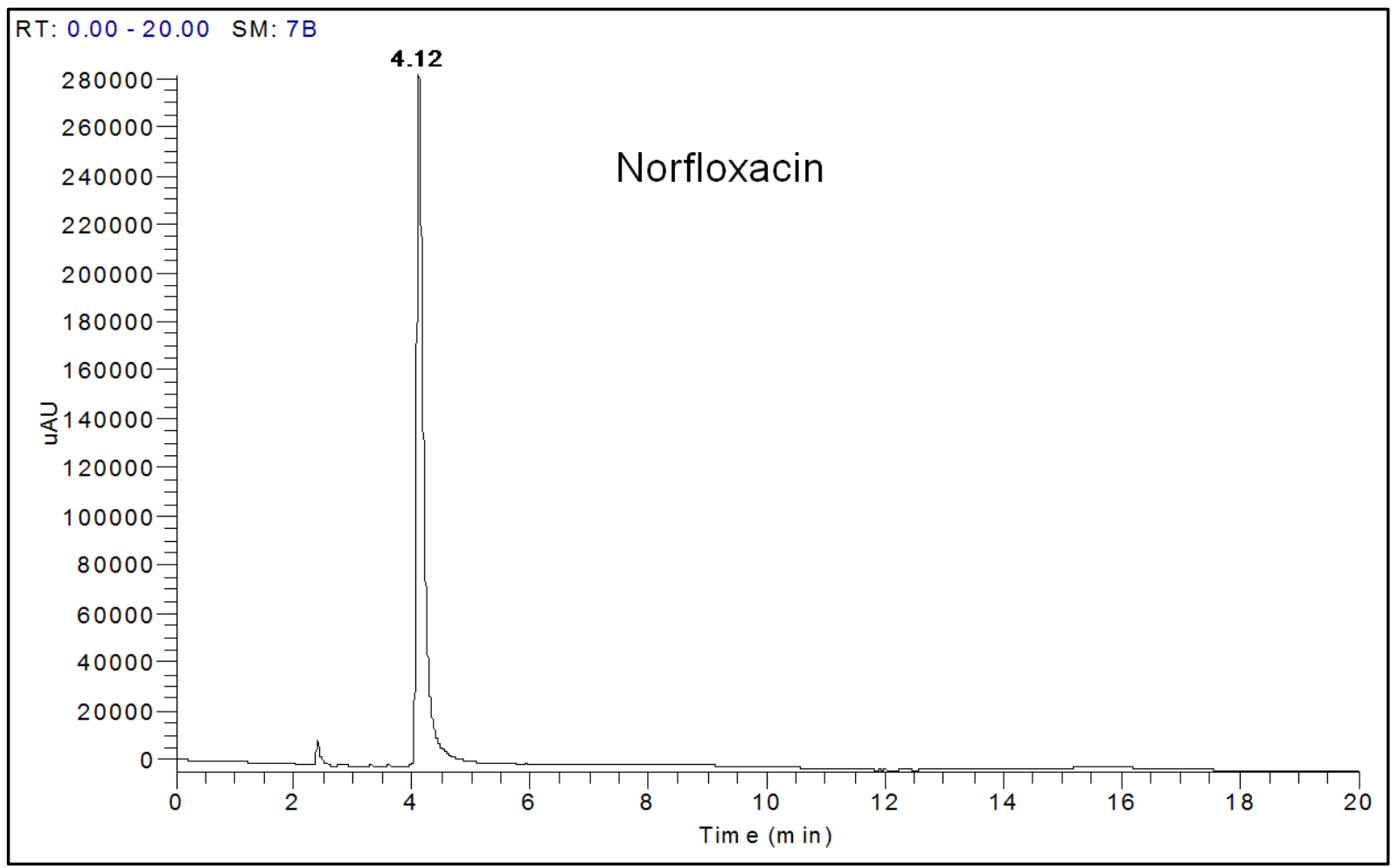

Figure S9 (a)

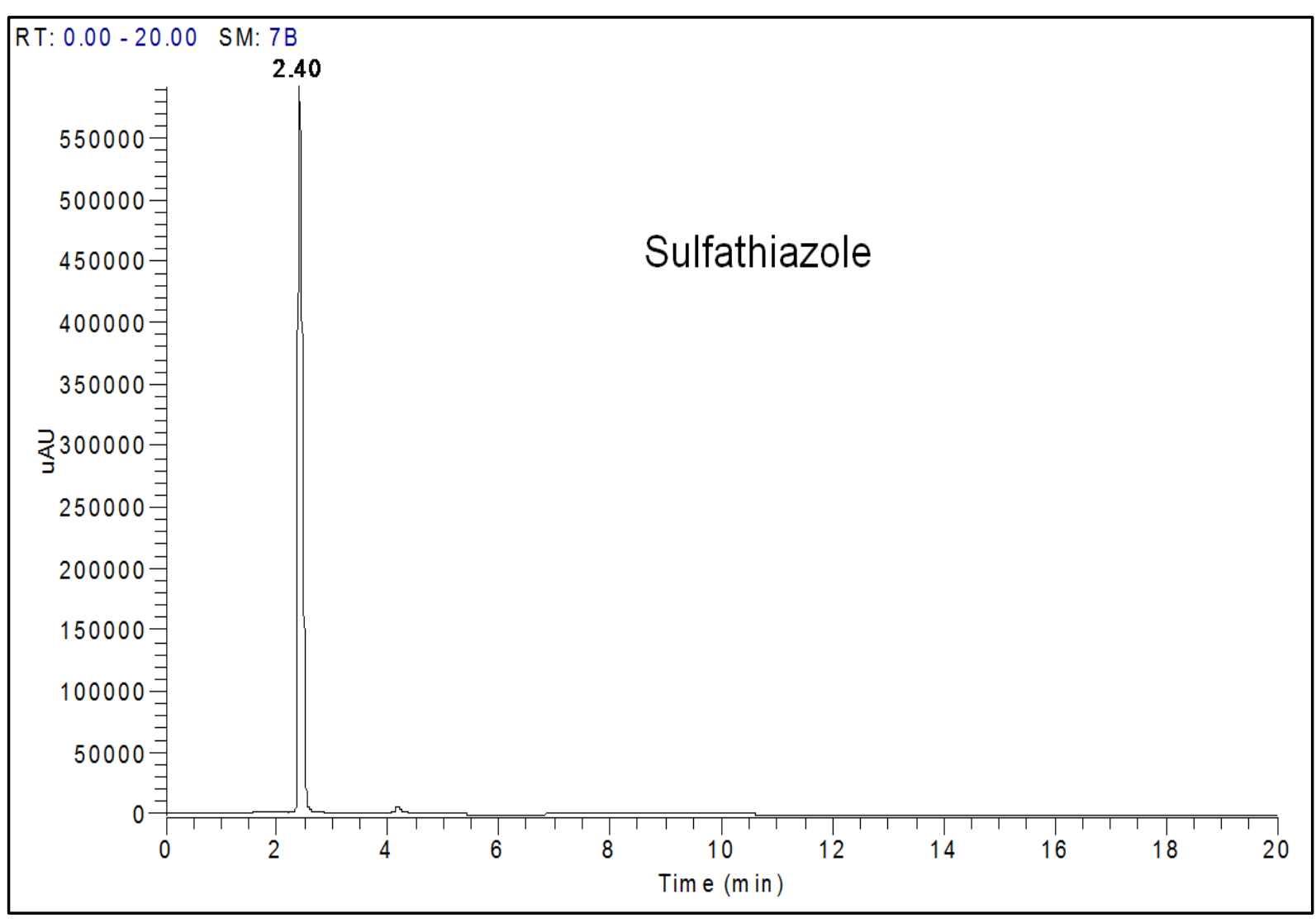

Figure S9 (b) 


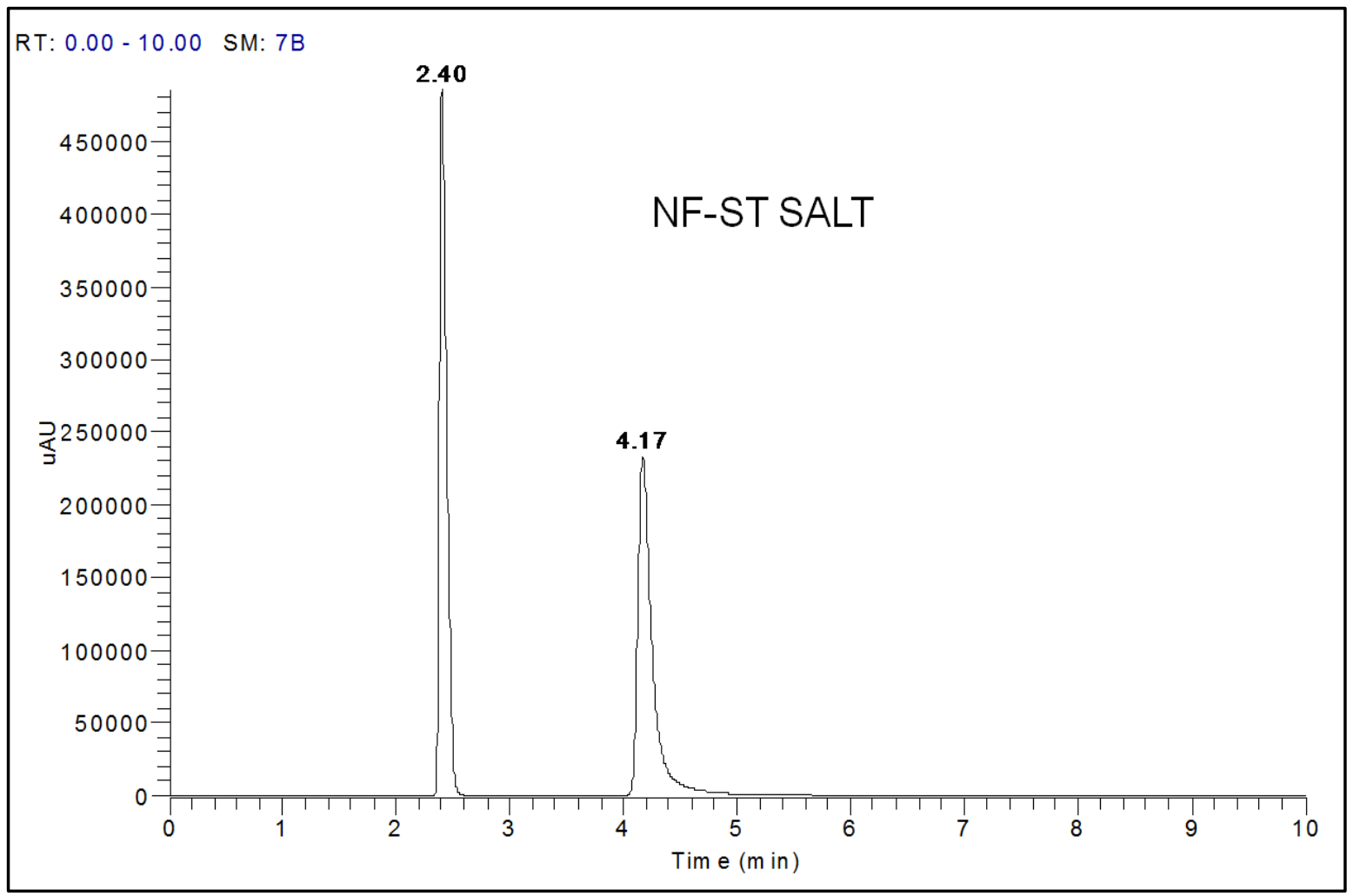

Figure S9 (c)

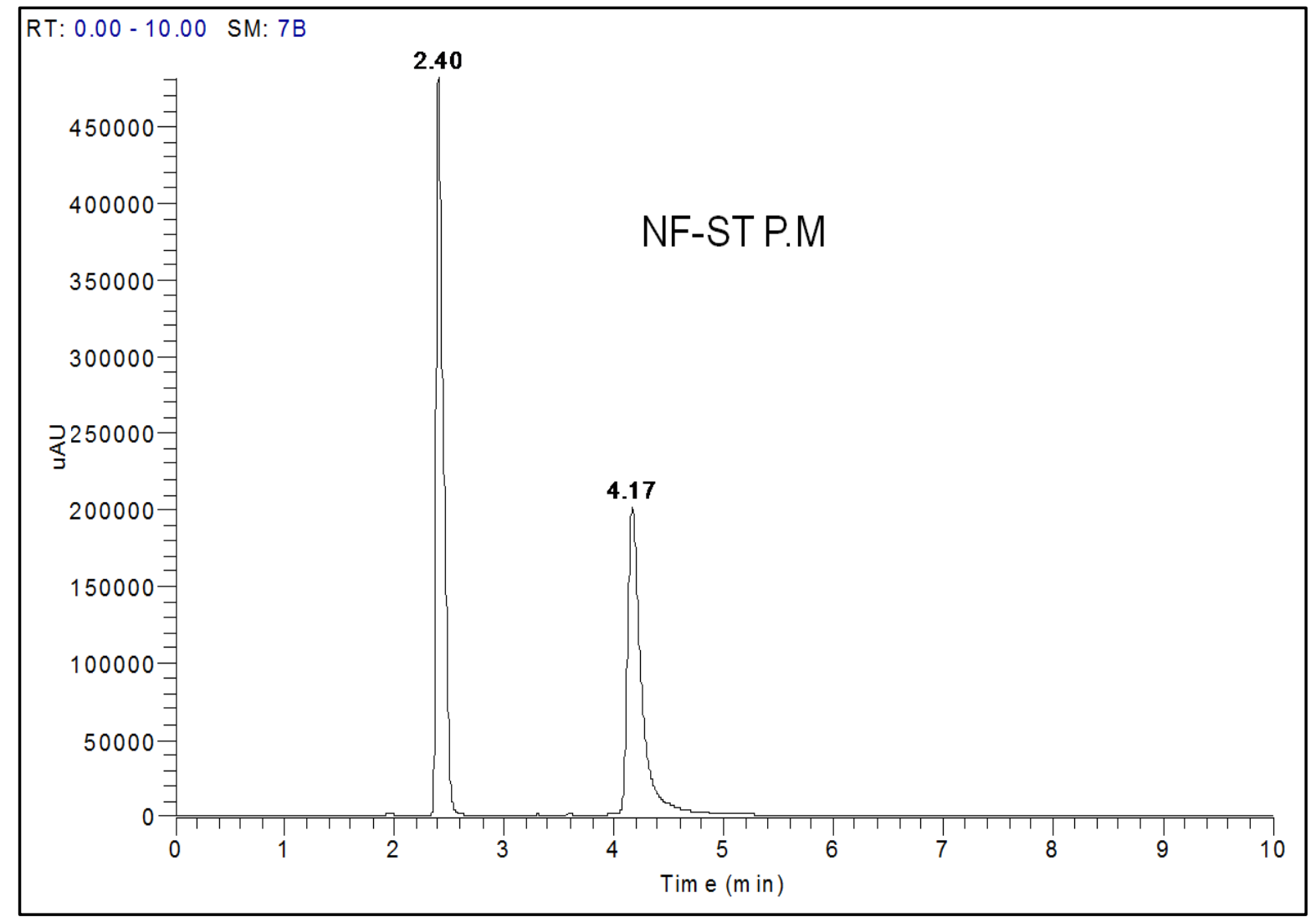

Figure S9 (d) 


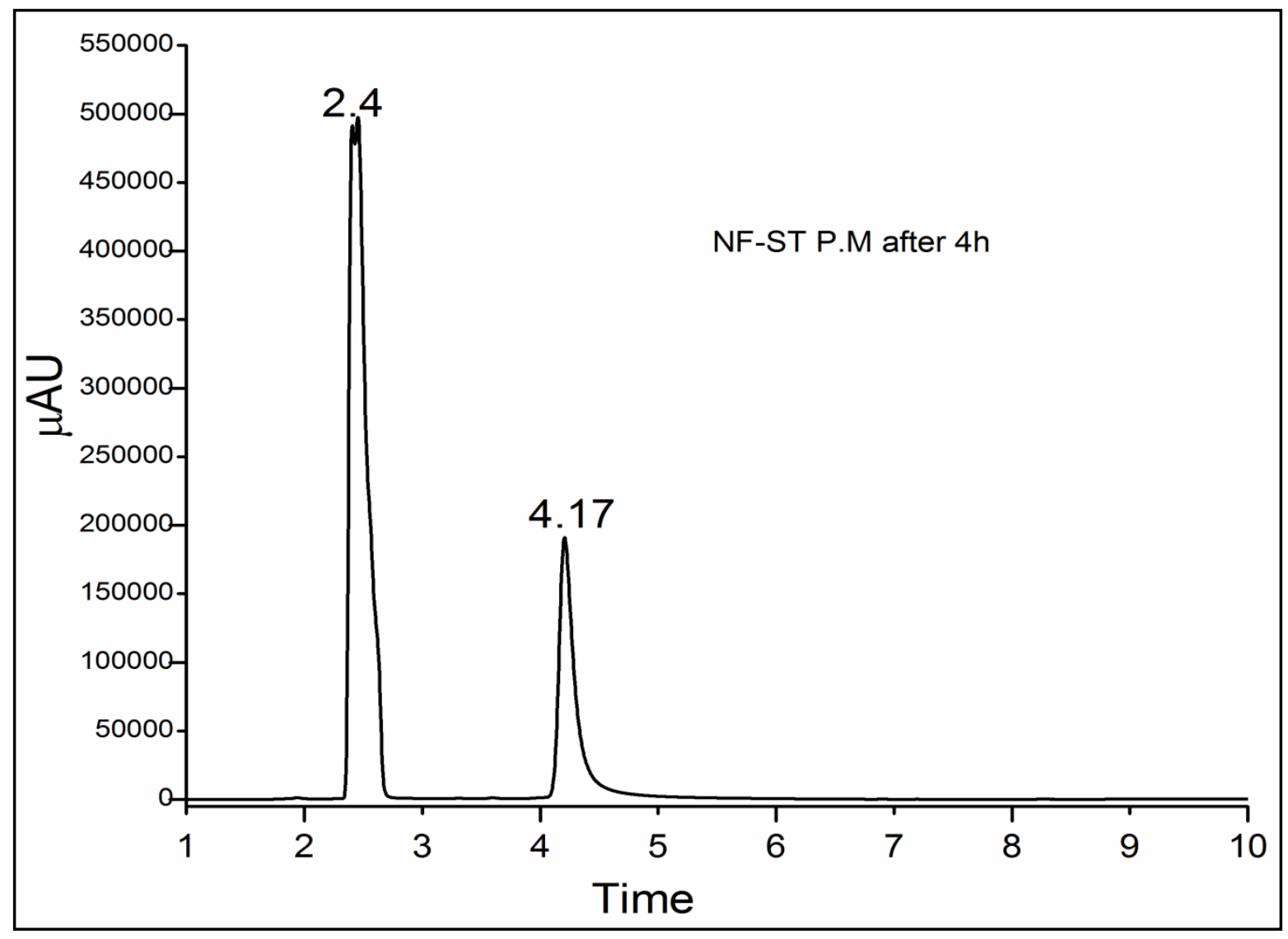

Figure S9 (e)

Figure S9. HPLC chromatograms of NF, ST, NF-ST salt and NF-ST physical mixtures

\section{Experimental details and characterization techniques}

Norfloxacin was obtained from Yarrow Chem Products, Mumbai, India and Sulfathiazole was from Sigma-Aldrich Chemicals, Bangalore, India, these were used directly for experiments without further purification. Melting points were measured on a Büchi melting point apparatus (Sigma Aldrich, Bangalore, India). Water filtered through a double distilled water purification system (Siemens, Ultra Clear, Germany) was used in all experiments. Fourier Transform infrared (FTIR) spectra were recorded using an ATR accessory on a Perkin Elmer (Frontier) spectrophotometer (4000-600 $\mathrm{cm}^{-1}$ ). Powder X-ray diffraction (PXRD) data was recorded using a PANalytical X-ray powder diffractometer (Cu-K $\alpha$ radiation, $\lambda=1.54056 \AA$ ) equipped with a $\mathrm{X}$ 'cellerator detector at room temperature with the scan range $2 \theta=5$ to $50^{\circ}$ and step size $0.026^{\circ}$. X'Pert HighScore Plus were used to compare the experimental PXRD pattern with the calculated lines from the crystal structure. DSC and TGA was performed to confirm purity of the new solids forms on a Mettler Toledo DSC $822^{\mathrm{e}}$ 
module and a Mettler Toledo TGA/SDTA 851e module, respectively with the heating rate of $5{ }^{\circ} \mathrm{C} / \mathrm{min}$ between the temperature range of $30-300{ }^{\circ} \mathrm{C}$ under nitrogen atmosphere. Intrinsic dissolution rate (IDR) experiments were carried using USP-certified Electrolab EDT-08 Lx Dissolution Tester (Mumbai, India).

\section{Single Crystal X-ray Diffraction:}

Single crystal X-ray data for all crystals were collected on a Rigaku Mercury 375/M CCD (XtaLAB mini) diffractometer using graphite monochromated Mo $\mathrm{K} \alpha$ radiation. The data were processed with the Rigaku Crystal clear software. Structure solution and refinements were executed using SHELX-97 using the WinGX suite of programs. Refinement of coordinates and anisotropic thermal parameters of non-hydrogen atoms were performed with the full-matrix least-squares method. The differing treatment of $\mathrm{H}$ atoms in $\mathrm{D}-\mathrm{H}$ in any structure depends on the data quality. The hydrogen atom position was located from difference Fourier map or calculated using riding model. PLATON software was used to prepare material for publication, and Mercury 3.7 was utilized for molecular representations and packing diagrams. Crystallographic cif files (CCDC Nos. 1452813-1452815) are available at www.ccdc.cam.ac.uk/data_request/cif

\section{Experimental procedures of solubility, diffusion and release rate studies}

Solubility Study: The absorption coefficient of each NF, ST and its salt was measured using the slope of absorbance $v$ s concentration of the five known concentrated solutions in $\mathrm{pH} 7.4$ phosphate buffer and in cosolvent (10\% Ethanol+7.4 phosphate buffer) and measurements were done at 271-272 $\mathrm{nm}$ on a PerkinElmer UV-vis spectrometer. The solubility of each solid was measured at $24 \mathrm{~h}$ using the shake flask method.

Diffusion Study: The diffusion studies of NF, ST and its salt was carried out using the modified Franz diffusion cell apparatus through a cellulose nitrate membrane $(0.45 \mu \mathrm{m}$, 11306, Sartorius, Germany). The dialysis membrane was pretreated with $10 \%$ of $\mathrm{NaHCO}_{3}$ at $70{ }^{\circ} \mathrm{C}$ for $20 \mathrm{~min}$ to remove traces of sulfides, followed by $10 \mathrm{mM}$ of EDTA at $70{ }^{\circ} \mathrm{C}$ for 20 min to remove the traces of heavy metal and $20 \mathrm{~min}$ of treatment with deionized water at $70{ }^{\circ} \mathrm{C}$ to remove glycerine followed by soaking the membrane in buffer for 15-20 minutes. The treated dialysis membrane was mounted in vertical static diffusion cells with an effective surface area of $4.5 \mathrm{~cm}^{2}$. The donor compartment contained $50 \mathrm{mg}$ of the drug and its respective cocrystals, and these were suspended in $2 \mathrm{~mL}$ of $\mathrm{pH} 7.4$ phosphate buffer. The receptor compartment was filled with $20 \mathrm{~mL}$ of phosphate buffer ( $\mathrm{pH} \mathrm{7.4),} \mathrm{maintained} \mathrm{at}$ 
room temperature, and bubbles were removed. Receptor solution was magnetically stirred at $45 \pm 5 \mathrm{rpm}$ to ensure medium homogeneity throughout the duration of the experiment. An aliquot of $2 \mathrm{~mL}$ of the sample was withdrawn from the receptor compartment at predetermined time intervals $1 \mathrm{~h}$ intervals for $12 \mathrm{~h}$ during the diffusion experiment and donor compartment was replaced with same amount of fresh medium. Diffusion study of NF, ST and its salt was carried out in triplicate. Samples were analyzed by UV-vis spectrophotometer at a $\lambda \max$ of 271-272 $\mathrm{nm}$ after suitable dilution.

Intrinsic dissolution rate (IDR) : IDR experiments (release rate studies) were carried out by rotating disk method taking $100 \mathrm{mg}$ of each material was taken in the intrinsic attachment and compressed to a $0.5 \mathrm{~cm}^{2}$ pellet using a hydraulic press at a pressure of 3-5 ton/inch2 for 2 min. The pellet was compressed to provide a flat surface at one end and the other end was sealed. The pellet was then dipped into $500 \mathrm{ml} \mathrm{pH} 7.4$ buffer medium at $37^{\circ} \mathrm{C}$ with the paddle rotating at $150 \mathrm{rpm}$. At regular intervals of one hour, $5 \mathrm{ml}$ of the dissolution medium was withdrawn and replaced by an equal volume of fresh medium to maintain a constant volume. Samples were filtered through $0.2 \mathrm{~mm}$ nylon filter and assayed for drug content samples using UV-vis spectrophotometer. The amount of drug dissolved in each time interval was calculated using the calibration curve.

Experimental details of HPLC: Based on trial and error method, the mobile phase which give best possible separation and resolution was selected and retention time was also taken in to the consideration. Finally the system containing $10 \mathrm{mM}$ Sodium dihydrogen phosphate buffer/ Acetonitrile/Methanol : 15:70:15 was found to be satisfactory in isocratic method (flow rate $1.0 \mathrm{~mL} / \mathrm{min}$, injection volume $10 \mu \mathrm{L}$, PDA adsorption wave length 200-600nm) and gave two well resolved peaks for ST and NF at 260-271 nm. The retention time for NF and ST was 4.12 minutes and 2.4 minutes respectively.

\section{Experimental procedure of in-vitro biological studies}

Minimum Inhibitory Concentration (MIC): Bacterial MICs were determined using different drug concentrations by microdilution broth method with Mueller-Hinton broth and disc diffusion technique. Serial twofold dilutions were made by using $50 \mu$ microdiluters. An equal volume of a suspension of organisms from a $24 \mathrm{~h}$ broth culture was added to each vial to a bacterial density of $10^{5} \mathrm{CFU} / \mathrm{ml}$. After 20 to $24 \mathrm{~h}$ of incubation at $37^{\circ} \mathrm{C}$, the MICs were 
determined as the lowest concentrations of antibiotic that completely inhibited growth using micro plate reader. Each experiment was repeated two times to find the final concentration for the MIC.

Antibacterial and Antimicrobial susceptibility test by Disc diffusion Technique : Disc impregnated with $25 \mu \mathrm{l}$ of the samples for bacterial and $20 \mu \mathrm{l}$ for microbial studies (salt and physical mixture) are placed on an agar plate that has been inoculated uniformly over the entire plate with a culture of the bacteria (E. coli and S. aureus and Aspergillus). The plates was labelled with the name of the culture, sample and stock at the middle of the first plate for anti bacterial test (E. coli and S. aureus) and in the case of Aspergillus control was kept in the corner of disk. The treated disks were incubated for 18 to 24 hours at $37{ }^{\circ} \mathrm{C}$ and after incubation the diameter of the zone of inhibition of growth was measured for bacterial studies and in the case of fungi disks were incubated for 3-4 days at room temperature and after incubation the diameter of the zone of inhibition of growth was measured. During this period, the antimicrobial agent diffuses through the agar and may prevent the growth of the organism. Effectiveness of susceptibility is proportional to the diameter of the inhibition zone around the disc. 